\title{
THE ROLE OF LOW MOLECULAR WEIGHT HEPARIN IN WOMEN WITH HEREDITARY THROMBOPHILIA FOR GOOD PERINATAL OUTCOME
}

\author{
Vesna Sokol ${ }^{1}$, Marina Ivanišević $^{1,2}$, Mislav $\operatorname{Herman}^{1}$ and Josip Đelmiš ${ }^{2}$ \\ ${ }^{1}$ Clinical Department of Gynecology and Obstetrics, Zagreb University Hospital Center; \\ ${ }^{2}$ University of Zagreb, School of Medicine, Zagreb, Croatia
}

\begin{abstract}
SUMMARY - The aim of the study was to establish the importance of low molecular weight heparin (LMWH) treatment for good pregnancy outcome in patients with hereditary thrombophilia. This retrospective study included 70 patients with inherited thrombophilia who gave birth at Zagreb University Hospital Center in the period from January 2014 to January 2015. Fifty-seven women were treated and 13 women were not treated with LMWH. Perinatal outcome was significantly better in women with hereditary thrombophilia who were treated with heparin during pregnancy as compared with women without LMWH ( $\mathrm{p}=0.006)$. Regardless of heparin therapy, patients with hereditary thrombophilia alone had a significantly better perinatal outcome as compared with women who, along with hereditary thrombophilia, had a history of habitual abortions $(\mathrm{p}=0.035)$ or intrauterine fetal death $(\mathrm{p}=0.033)$. Women treated with heparin had better perinatal outcome if they were without a history of recurrent or non-recurrent fetal loss $(\mathrm{p}=0.088)$. In the group without $\mathrm{LMWH}$, perinatal outcome was significantly better in women with no history of habitual abortions as compared with women with recurrent miscarriages $(\mathrm{p}=0.047)$. Administration of $\mathrm{LMWH}$ is justified in women with hereditary thrombophilia and a history of adverse perinatal outcome.
\end{abstract}

Key words: Thrombophilia, hereditary; Pregnancy; Heparin, low-molecular-weight; Pregnancy outcome

\section{Introduction}

Thrombophilias are inherited or acquired conditions that create a hypercoagulable state which predisposes the individual to thromboembolism ${ }^{1-3}$. Inherited defects related to thrombosis include the G1691A mutation in the factor $\mathrm{V}$ gene, the G20210A mutation in the prothrombin gene, the C677T mutation and the A1298C mutation in the methylenetetrahydrofolate reductase (MTHFR) gene, antithrombin III, protein $\mathrm{C}$ and protein $\mathrm{S}$ deficiency ${ }^{4}$. The most entrenched acquired thrombophilia is the antiphospolipid syndrome, a non-inflammatory autoimmune disease character-

Correspondence to: Vesna Sokol, MD, Clinical Department of Gynecology and Obstetrics, Zagreb University Hospital Center, Petrova 13, HR-10000 Zagreb, Croatia

E-mail: vesnasokol83@yahoo.com

Received January 13, 2016, accepted February 25, 2016 ized by the presence of antiphospholipid antibodies. Antiphospholipid syndrome can be either primary or secondary to another autoimmune disease. The overall impact of inherited and acquired thrombophilias is low in non-pregnant population and the majority of patients never experience a thrombotic event. During pregnancy, however, the thrombogenic potential of these disorders is enhanced because of the hypercoagulable state produced by normal pregnancy-associated changes with which the mother's body adjusts to pregnancy and later on to childbirth. Such changes occur in the blood flow, vascular wall and coagulation factors (increased levels of factors VII, VII, X and von Willebrand's factor, decreased activity levels of protein C and protein $\mathrm{S}$, and increased activity level of fibrinolytic inhibitors) ${ }^{4}$.

Whereas in recent years numerous studies have established the association between acquired thrombo- 
philias and adverse pregnancy outcome ${ }^{5-7}$, inherited thrombophilia and related complications in pregnancy still remain debatable ${ }^{8,9}$. Available evidence does not support an association between inherited thrombophilia and preeclampsia, fetal growth restriction, or abruption, and, in turn, it does not support prophylactic anticoagulation to prevent the possible adverse pregnancy outcomes in patients with hereditary thrombophilias ${ }^{10}$. However, adverse medical and obstetric history in patients with inherited thrombophilia requires special caution for good outcome of the current pregnancy.

The aim of the study was to establish the role of low molecular weight heparin (LMWH) in patients with inherited thrombophilia for good pregnancy outcome, with special emphasis on the women with adverse obstetric history, and to identify the common types of mutation in the study group.

\section{Patients and Methods}

This retrospective epidemiological study was conducted at the State Referral Center for Diabetes in Pregnancy, Zagreb University Hospital Center, Zagreb, Croatia, during the period from January 2014 to January 2015. The study included 70 patients diagnosed with hereditary thrombophilia. All enrolled patients delivered in our hospital but the majority of them had their regular examinations and treatment provided by their physicians in primary or secondary health care centers. Patients were classified into two groups: 57 women with hereditary thrombophilia that were treated with LMWH and 13 women not treated with LMWH despite the diagnosis of inherited thrombophilia. Patient characteristics including demographics, obstetric and medical history were obtained from patients at the hospital visit and entered in the database. Data on pregnancy outcomes were obtained from the delivery suite database.

\section{Statistical analysis}

All statistical analyses were performed using the SPSS for Windows, release 17 (SPSS Inc., Chicago, IL, USA). For quantitative measurements (continuous), the mean and standard deviation was calculated. For qualitative measurements, absolute frequency was calculated and prevalence was expressed as percentage. The $\chi^{2}$-test was used on comparison of qualitative data.
All the variables collected were statistically analyzed and presented descriptively. Inferential statistical analysis aimed to investigate the relationship between the use of LMWH in women with thrombophilic mutations and their perinatal outcome. The level of statistical significance was set at $\mathrm{p}<0.05$.

\section{Results}

A total of 70 women with inherited thrombophilia who gave birth at the Zagreb University Hospital Center were recruited during the study period. The mean age of study patients was $34.2 \pm 4$ years, range 20 45 years. The mean body mass index was 25.7 (range 18-35). The minimum number of pregnancies was 1

Table 1. Demographic characteristics of patients with hereditary thrombophilia

\begin{tabular}{|l|l|}
\hline Characteristic & Patients with HT \\
\hline $\begin{array}{l}\text { Age } \\
\text { (years; mean } \pm \text { SD and range) }\end{array}$ & $34.2 \pm 4.40(20.0-45.0)$ \\
\hline $\begin{array}{l}\text { BMI } \\
\left(\mathrm{kg} / \mathrm{m}^{2} ; \text { mean } \pm \mathrm{SD} \text { and range) }\right.\end{array}$ & $25.7 \pm 5.21(18.0-35.0)$ \\
\hline $\begin{array}{l}\text { Gravidity } \\
(\mathrm{n} ; \text { mean } \pm \mathrm{SD} \text { and range) }\end{array}$ & $2.9 \pm 1.51(1.0-9.0)$ \\
\hline $\begin{array}{l}\text { Parity } \\
\text { (n; mean } \pm \mathrm{SD} \text { and range) }\end{array}$ & $0.7 \pm 0.74(0.0-2.0)$ \\
\hline $\begin{array}{l}\text { Abortion } \\
(\mathrm{n} \text {; mean } \pm \mathrm{SD} \text { and range })\end{array}$ & $1.3 \pm 1.36(0.0-7.0)$ \\
\hline
\end{tabular}

$\mathrm{HT}=$ hereditary thrombophilia; $\mathrm{BMI}=$ body mass index; $\mathrm{SD}=$ standard deviation; $\mathrm{n}=$ number

Table 2. History of comorbidity in patients with hereditary thrombophilia

\begin{tabular}{|l|c|}
\hline History of comorbidity & $\mathrm{n}(\%)$ \\
\hline Primary or secondary infertility & $9(12.5)$ \\
- IVF in current pregnancy & $6(6.6)$ \\
\hline Hypertensive disorders & $6(8.5)$ \\
- PIH & $3(50)$ \\
- PE & $3(50)$ \\
\hline GDM & $8(11.4)$ \\
\hline T1D & $1(1.4)$ \\
\hline T2D & $1(1.4)$ \\
\hline
\end{tabular}

$\mathrm{n}=$ number IVF $=$ in vitro fertilization; $\mathrm{PIH}=$ pregnancy induced hypertension; $\mathrm{PE}=$ preeclampsia; $\mathrm{GDM}=$ gestational diabetes mellitus; T1D = diabetes mellitus type $1 ; \mathrm{T} 2 \mathrm{D}=$ diabetes mellitus type 2 
Table 3. Type of mutation for hereditary thrombophilia in the study group

\begin{tabular}{|c|c|c|}
\hline Mutation & $\mathrm{n}$ & $\%$ \\
\hline PAI 1 homozygous & 12 & 10.8 \\
\hline MTHFR heterozygous (C677T), PAI1 (4G/5G) homozygous & 11 & 9.9 \\
\hline PAI1 heterozygous & 10 & 9.0 \\
\hline PAI1 homozygous, MTHFR homozygous & 6 & 5.4 \\
\hline FVL heterozygous, PAI1 heterozygous & 5 & 4.5 \\
\hline PAI1 heterozygous, MTFHFR heterozygous & 5 & 4.5 \\
\hline FII heterozygous, PAI1 homozygous, MTHFR homozygous & 4 & 3.6 \\
\hline MTHFR homozygous, PAI1 heterozygous & 3 & 2.7 \\
\hline FVL heterozygous & 2 & 1.8 \\
\hline FII heterozygous & 2 & 1.8 \\
\hline PAI1 homozygous, protein S deficiency & 1 & 0.9 \\
\hline MTHFR homozygous, FVL heterozygous & 1 & 0.9 \\
\hline MTHFR homozygous, PAI1 heterozygous, FVL heterozygous & 1 & 0.9 \\
\hline MTHFR heterozygous, PAI1 homozygous, protein S deficiency & 1 & 0.9 \\
\hline MTHFR heterozygous & 1 & 0.9 \\
\hline PAI1 heterozygous, MTHFR heterozygous, FVL heterozygous & 1 & 0.9 \\
\hline FVL homozygous, PAI1 heterozygous & 1 & 0.9 \\
\hline FII homozygous, FVL heterozygous, PAI1 homozygous, MTHFR heterozygous & 1 & 0.9 \\
\hline MTHFR heterozygous, PAI1 heterozygous, protein C and protein S deficiency & 1 & 0.9 \\
\hline Antithrombin III deficiency, PAI1 heterozygous & 1 & 0.9 \\
\hline
\end{tabular}

Table 4. Classification of mutations in the study group

\begin{tabular}{|l|c|}
\hline Type of mutation & $\mathrm{n}(\%)$ \\
\hline Isolated & $27(38.6)$ \\
Combined & $43(61.4)$ \\
Total & $70(100.0)$ \\
\hline
\end{tabular}

and maximum 9, with a mean value of 2.9. The minimum number of deliveries was 0 and maximum 2 , and the mean number of abortions was 1.37 (range $0-7$ ) (Table 1).

Six (8.5\%) women experienced venous thromboembolism before their pregnancy. These pregnant women were found to have a family history of venous thromboembolism, myocardial infarction or stroke in first-degree relatives younger than 50 . The prevalence of this history was $15.7 \%$ (11 patients).

Nine (12.5\%) women with inherited thrombophilia had a diagnosis of primary or secondary infertility and six (6.6\%) of them conceived using in vitro fertilization (IVF). Six (8.5\%) patients had hypertensive disorders such as gestational hypertension and preeclampsia (50\% both), and eight (11.4\%) women were diagnosed with gestational diabetes (Table 2).

All study women had DNA blood tests that confirmed gene mutations for hereditary thrombophilia. Twenty different combinations of gene mutations were identified (Table 3).

Given the high prevalence of different types of mutations in the study group, the mutations were classified as isolated $(\mathrm{n}=27 ; 38.6 \%)$ and combined $(\mathrm{n}=43$; 38.7\%) (Table 4).

Analysis of medical records found that treatment with heparin was based on obstetric and family history, as well as on the type of mutation for hereditary thrombophilia.

Using Pearson's $\chi^{2}$-test, we analyzed perinatal outcome in all women with hereditary thrombophilia (Table 5), in women with hereditary thrombophilia treated with LMWH (Table 6) and in women with hereditary thrombophilia not treated with $\mathrm{LMWH}$ (Table 7). 
Table 5. Perinatal outcome in women with hereditary thrombophilia $(N=70)$

\begin{tabular}{|c|c|c|c|c|c|c|c|c|c|c|c|}
\hline \multirow{3}{*}{\multicolumn{2}{|c|}{ Patients with HT }} & \multicolumn{10}{|c|}{ Perinatal outcome } \\
\hline & & \multicolumn{2}{|c|}{ Good } & \multicolumn{2}{|c|}{ IUGR } & \multicolumn{2}{|c|}{$\begin{array}{l}\text { Placental } \\
\text { abruption }\end{array}$} & \multicolumn{2}{|c|}{ Miscarriage } & \multicolumn{2}{|c|}{$\mathrm{PE}$} \\
\hline & & $\mathrm{n}$ & $\%$ & $\mathrm{n}$ & $\%$ & $\mathrm{n}$ & $\%$ & $\mathrm{n}$ & $\%$ & $\mathrm{n}$ & $\%$ \\
\hline \multirow{2}{*}{$\begin{array}{l}\text { LMWH } \\
\text { treatment }\end{array}$} & No & 7 & $53.8 \%$ & 2 & $15.4 \%$ & 0 & $0.0 \%$ & 4 & $30.8 \%$ & 0 & $0.0 \%$ \\
\hline & Yes & 47 & $82.5 \%$ & 6 & $10.5 \%$ & 2 & $3.5 \%$ & 1 & $1.8 \%$ & 1 & $1.8 \%$ \\
\hline \multirow{2}{*}{ Type of mutation } & Isolated & 19 & $70.4 \%$ & 4 & $14.8 \%$ & 1 & $3.7 \%$ & 3 & $11.1 \%$ & 0 & $0.0 \%$ \\
\hline & Combined & 35 & $81.4 \%$ & 4 & $9.3 \%$ & 1 & $2.3 \%$ & 2 & $4.7 \%$ & 1 & $2.3 \%$ \\
\hline \multirow{2}{*}{ Habitual abortion } & No & 29 & $76.3 \%$ & 7 & $18.4 \%$ & 1 & $2.6 \%$ & 0 & $0.0 \%$ & 1 & $2.6 \%$ \\
\hline & Yes & 25 & $78.1 \%$ & 1 & $3.1 \%$ & 1 & $3.1 \%$ & 5 & $15.6 \%$ & 0 & $0.0 \%$ \\
\hline \multirow{2}{*}{$\begin{array}{l}\text { IUFD in previous } \\
\text { pregnancies }\end{array}$} & No & 45 & $78.9 \%$ & 6 & $10.5 \%$ & 0 & $0.0 \%$ & 5 & $8.8 \%$ & 1 & $1.8 \%$ \\
\hline & Yes & 9 & $69.2 \%$ & 2 & $15.4 \%$ & 2 & $15.4 \%$ & 0 & $0.0 \%$ & 0 & $0.0 \%$ \\
\hline
\end{tabular}

\begin{tabular}{|l|l|c|}
\hline \multirow{2}{*}{ Patients with HT } & $\begin{array}{c}\text { Perinatal } \\
\text { outcome }\end{array}$ \\
\hline \multirow{2}{*}{$\begin{array}{l}\text { LMWH } \\
\text { treatment }\end{array}$} & $\chi^{2}$ & 14.502 \\
\cline { 2 - 3 } Type of mutation & Df & 4 \\
\cline { 2 - 3 } & $\mathrm{P}$ & 0.006 \\
\hline \multirow{3}{*}{ Habitual abortion } & $\chi^{2}$ & 2.409 \\
\cline { 2 - 3 } & $\mathrm{Df}$ & 4 \\
\cline { 2 - 3 } & $\mathrm{P}$ & 0.661 \\
\hline \multirow{3}{*}{ IUFD in previous pregnancies } & $\chi^{2}$ & 10.358 \\
\cline { 2 - 3 } & $\mathrm{Df}$ & 4 \\
\cline { 2 - 3 } & $\chi^{2}$ & 0.035 \\
\cline { 2 - 3 } & $\mathrm{Df}$ & 40.486 \\
\cline { 2 - 3 } & $\mathrm{P}$ & 0.033 \\
\hline
\end{tabular}

HT = hereditary thrombophilia; IUGR = intrauterine growth restriction; $\mathrm{PE}=$ preeclampsia; $\mathrm{n}=$ number $; \mathrm{LMWH}=$ low molecular weight heparin; IUFD = intrauterine fetal death

Adverse perinatal outcome such as intrauterine growth restriction (IUGR), intrauterine fetal death (IUFD), placental abruption, abortion and preeclampsia (PE) was observed.

According to study results, patients with hereditary thrombophilia that received LMWH had a significantly better perinatal outcome as compared with the group without LMWH ( $\mathrm{p}=0.006)$.

The abortion rate was lower in the group with LMWH; however, this group had a higher incidence of placental abruption. There were no significant differences according to the type of mutation (isolated and combined) and perinatal outcome $(\mathrm{p}=0.661)$.

Regardless of LMWH, women without habitual abortions had a significantly better perinatal outcome as compared with women with recurrent miscarriages (with emphasis on recurrent spontaneous abortion) $(p=0.035)$. Nevertheless, women with no history of adverse perinatal outcome had a significantly better pregnancy outcome as compared with women with a history of IUFD $(\mathrm{p}=0.033)$. The latter group showed a higher incidence $(15.6 \%)$ of placental abruption in the observed pregnancy (Table 5).

In the group of women with hereditary thrombophilia treated with LMWH, we found no association between the type of mutation (isolated or combined) and perinatal outcome $(\mathrm{p}=0.636)$. In the same group, there was no significant difference in perinatal outcome between the women with normal pregnancy outcome and those with habitual abortions in previous pregnancies $(\mathrm{p}=0.398)$. Although there was no significant difference in perinatal outcome between women with normal pregnancy outcome and those with IUFD in previous pregnancies $(\mathrm{p}=0.088)$, women with IUFD in previous pregnancies had a higher incidence of placental abruption in the observed pregnancy (15.4\%) (Table 6).

In the group of women with hereditary thrombophilia but without LMWH treatment, we found no association between the type of mutation (isolated or combined) and perinatal outcome $(\mathrm{p}=0.380)$. Patients with no history of adverse perinatal outcome had a significantly better perinatal outcome than women with a history of recurrent miscarriages $(p=0.047)$. In this group, there was no patient with a history of IUFD. 
Table 6. Perinatal outcome in women with hereditary thrombophilia treated with low molecular weight heparin $(N=57)$

\begin{tabular}{|c|c|c|c|c|c|c|c|c|c|c|c|}
\hline \multirow{3}{*}{\multicolumn{2}{|c|}{$\begin{array}{l}\text { Patients with HT treated with } \\
\text { LMWH }\end{array}$}} & \multicolumn{10}{|c|}{ Perinatal outcome } \\
\hline & & \multicolumn{2}{|c|}{ Good } & \multicolumn{2}{|c|}{ IUGR } & \multicolumn{2}{|c|}{$\begin{array}{l}\text { Placental } \\
\text { abruption }\end{array}$} & \multicolumn{2}{|c|}{ Miscarriage } & \multicolumn{2}{|c|}{$\mathrm{PE}$} \\
\hline & & $\mathrm{n}$ & $\%$ & $\mathrm{n}$ & $\%$ & $\mathrm{n}$ & $\%$ & $\mathrm{n}$ & $\%$ & $\mathrm{n}$ & $\%$ \\
\hline \multirow{2}{*}{ Type of mutation } & Isolated & 18 & $78.3 \%$ & 3 & $13.0 \%$ & 1 & $4.3 \%$ & 1 & $4.3 \%$ & 0 & $0.0 \%$ \\
\hline & Combined & 29 & $85.3 \%$ & 3 & $8.8 \%$ & 1 & $2.9 \%$ & 0 & $0.0 \%$ & 1 & $2.9 \%$ \\
\hline \multirow{2}{*}{ Habitual abortion } & No & 25 & $78.1 \%$ & 5 & $15.6 \%$ & 1 & $3.1 \%$ & 0 & $0.0 \%$ & 1 & $3.1 \%$ \\
\hline & Yes & 22 & $88.0 \%$ & 1 & $4.0 \%$ & 1 & $4.0 \%$ & 1 & $4.0 \%$ & 0 & $0.0 \%$ \\
\hline \multirow{2}{*}{$\begin{array}{l}\text { IUFD in previous } \\
\text { pregnancies }\end{array}$} & No & 38 & $86.4 \%$ & 4 & $9.1 \%$ & 0 & $0.0 \%$ & 1 & $2.3 \%$ & 1 & $2.3 \%$ \\
\hline & Yes & 9 & $69.2 \%$ & 2 & $15.4 \%$ & 2 & $15.4 \%$ & 0 & $0.0 \%$ & 0 & $0.0 \%$ \\
\hline
\end{tabular}

\begin{tabular}{|l|l|c|}
\hline $\begin{array}{l}\text { Patients with HT treated with } \\
\text { LMWH }\end{array}$ & $\begin{array}{c}\text { Perinatal } \\
\text { outcome }\end{array}$ \\
\hline \multirow{3}{*}{ Type of mutation } & $\chi^{2}$ & 2.549 \\
\cline { 2 - 3 } & $\mathrm{Df}$ & 4 \\
\cline { 2 - 3 } & $\mathrm{P}$ & 0.636 \\
\hline Habitual abortion & $\chi^{2}$ & 4.060 \\
\cline { 2 - 3 } & $\mathrm{Df}$ & 4 \\
\cline { 2 - 3 } & $\mathrm{P}$ & 0.398 \\
\hline IUFD in previous pregnancies & $\chi^{2}$ & 8.095 \\
\cline { 2 - 3 } & $\mathrm{Df}$ & 4 \\
\cline { 2 - 3 } & $\mathrm{P}$ & 0.088 \\
\hline
\end{tabular}

HT = hereditary thrombophilia; IUGR = intrauterine growth restriction; $\mathrm{PE}=$ preeclampsia; $\mathrm{n}$ = number; $\mathrm{LMWH}=$ low molecular weight heparin; IUFD = intrauterine fetal death

Unfortunately, the number of cases in this group was too small to obtain meaningful data (Table 7).

\section{Discussion}

Thrombophilia in mothers, in addition to natural hemostatic changes in every pregnancy, also changes placental circulation ${ }^{11,12}$. Thromboses of maternal placenta may cause complications such as preeclampsia and IUGR, as well as more serious complications such as miscarriage, placental abruption and IUFD. $\mathrm{Nu}^{-}$ merous studies have evaluated the correlation between thrombophilia and pathologic perinatal outcome. Even though some retrospective studies argue there is a link between certain mutations (heterozygous factor $\mathrm{V}$ Leiden, heterozygous prothrombin gene, protein $\mathrm{C}$ and $\mathrm{S}$ deficiency) and missed abortions after 10 weeks of gestation, recurrent miscarriages and IUFD after 20 weeks of gestation, the majority of prospective studies deny this causal connection ${ }^{13-15}$.

Our study included a heterogeneous group of women of different age groups, different family and personal history, and different reasons for genetic testing for hereditary thrombophilia. Different widespread mutations and their combinations found in our geographical area reflected in our study group, with a predominance of so-called 'mild mutations' such as PAI1 and MTHFR, and a lesser percentage of 'severe mutations' such as factor V Leiden and factor II mutations. Despite the already inveterate opinion that hereditary thrombophilia has a negligible impact on perinatal outcome, women in our study that were administered LMWH had a statistically much better perinatal outcome than women that did not receive this therapy, irrespective of the mutation type $(\mathrm{p}=0.006)$. Women treated with heparin experienced a lower percentage of miscarriages; however, more cases of placental abruption were recorded in this group. Furthermore, an unfortunate outcome of previous pregnancies (e.g., recurrent miscarriages, IUFD) also led to worse perinatal outcome of the observed pregnancies. It is important to highlight that all the observed women with hereditary thrombophilia and recurrent miscarriages that were not treated with heparin had a statistically worse perinatal outcome as compared with women who were not treated with heparin either but had unremarkable obstetric history.

This study results supported the Royal College of Obstetricians and Gynaecologists Green-top guidelines, clearly stressing the importance of LMWH for better perinatal outcome in pregnant women with he- 
Table 7. Perinatal outcome in women with hereditary thrombophilia without low molecular weight heparin treatment $(N=13)$

\begin{tabular}{|c|c|c|c|c|c|c|c|c|c|c|c|}
\hline \multirow{3}{*}{\multicolumn{2}{|c|}{$\begin{array}{l}\text { Patients with HT without } \\
\text { LMWH treatment }\end{array}$}} & \multicolumn{10}{|c|}{ Perinatal outcome } \\
\hline & & \multicolumn{2}{|c|}{ Good } & \multicolumn{2}{|c|}{ IUGR } & \multicolumn{2}{|c|}{$\begin{array}{l}\text { Placental } \\
\text { abruption }\end{array}$} & \multicolumn{2}{|c|}{ Miscarriage } & \multicolumn{2}{|c|}{$\mathrm{PE}$} \\
\hline & & $\mathrm{n}$ & $\%$ & $\mathrm{n}$ & $\%$ & $\mathrm{n}$ & $\%$ & $\mathrm{n}$ & $\%$ & $\mathrm{n}$ & $\%$ \\
\hline \multirow{2}{*}{ Type of mutation } & Isolated & 1 & $25.0 \%$ & 1 & $25.0 \%$ & 0 & $0.0 \%$ & 2 & $50.0 \%$ & 0 & $0.0 \%$ \\
\hline & Combined & 6 & $66.7 \%$ & 1 & $11.1 \%$ & 0 & $0.0 \%$ & 2 & $22.2 \%$ & 0 & $0.0 \%$ \\
\hline \multirow{2}{*}{$\begin{array}{l}\text { Habitual } \\
\text { abortion }\end{array}$} & No & 4 & $66.7 \%$ & 2 & $33.3 \%$ & 0 & $0.0 \%$ & 0 & $0.0 \%$ & 0 & $0.0 \%$ \\
\hline & Yes & 3 & $42.9 \%$ & 0 & $0.0 \%$ & 0 & $0.0 \%$ & 4 & $57.1 \%$ & 0 & $0.0 \%$ \\
\hline \multirow{2}{*}{$\begin{array}{l}\text { IUFD in previous } \\
\text { pregnancies }\end{array}$} & No & 7 & $53.8 \%$ & 2 & $15.4 \%$ & 0 & $0.0 \%$ & 4 & $30.8 \%$ & 0 & $0.0 \%$ \\
\hline & Yes & 0 & $0.0 \%$ & 0 & $0.0 \%$ & 0 & $0.0 \%$ & 0 & $0.0 \%$ & 0 & $0.0 \%$ \\
\hline
\end{tabular}

\begin{tabular}{|l|l|c|}
\hline \multicolumn{2}{|l|}{$\begin{array}{l}\text { Patients with HT without LMWH } \\
\text { treatment }\end{array}$} & $\begin{array}{c}\text { Perinatal } \\
\text { outcome }\end{array}$ \\
\hline Type of mutation & $\chi^{2}$ & 1.935 \\
\cline { 2 - 3 } & Df & 2 \\
\cline { 2 - 3 } Habitual abortion & $\mathrm{P}$ & 0.380 \\
\hline & $\chi^{2}$ & 6.102 \\
\cline { 2 - 3 } & $\mathrm{Df}$ & 2 \\
\hline & $\mathrm{P}$ & 0.047 \\
\hline
\end{tabular}

HT = hereditary thrombophilia; IUGR = intrauterine growth restriction; $\mathrm{PE}=$ preeclampsia; $\mathrm{n}=$ number LMWH = low molecular weight heparin; IUFD = intrauterine fetal death

reditary thrombophilia and pathologic perinatal outcomes in previous pregnancies, especially recurrent trimester II miscarriages or IUFD ${ }^{16}$.

It is concluded that, regardless of the mutation type, hereditary thrombophilia, in addition to complicated obstetric history, requires and justifies LMWH therapy administration for the purpose of a favorable perinatal outcome. This is especially true for patients with a complicated family history.

Thrombophilia is a widespread gene mutation, mostly detected incidentally when one's clinical features are provoked by a state of hypercoagulability, such as pregnancy. Recurrent pathologic outcomes of pregnancies in mutation-carrying women indicate the body's struggle to adjust to the new setting. Numerous contradictory results of various studies on the thrombophilia effect on perinatal outcome can be ascribed to small test groups, different diagnostic criteria and predominantly retrospective study design. Studies on greater test groups are needed to clarify the real effect of certain mutations on pregnancies. Administration of heparin can help the body fight for a better perinatal outcome, especially in women who have already lost the battle in past pregnancies. According to our results, LMWH proved to be the treatment of choice in patients with adverse pregnancy events in which thrombophilic mutations were identified.

\section{References}

1. Lockwood CJ. Heritable coagulopathies in pregnancy. Obstet Gynecol Surv. 1999 Dec;54:754-65.

2. Walker MC, Garner PR Keely EJ, Rock GA, Reis MD. Changes in activated protein $\mathrm{C}$ resistance during normal pregnancy. Am J Obstet Gynecol. 1997 Jul;177(1):162-9. doi: 10.1016/S0002-9378(97)70456-3

3. Comp PC, Thurnau GR, Welsh J, Esmon CT. Functional and immunologic protein $\mathrm{S}$ levels are decreased during pregnancy. Blood. 1986 Oct;68(4):881-5.

4. Brenner B. Inherited thrombophilia and pregnancy loss. Best Pract Res Clin Haematol. 2003;16(2):311-20. doi: 10.1016/ S1521-6926(02)00097-X

5. Chighizola CB, Gerosa M, Trespidi L, Di Giacomo A, Rossi F, Acaia B, et al. Update on the current recommendations and outcomes in pregnant women with antiphospolipid syndrome. Expert Rev Clin Immunol. 2014 Nov;10(11):1505-17. doi: 10.158/6/1744666X.2014.968129

6. Cetković A, Kastratović B, Novaković I. Prospective study of perinatal outcome in pregnancies with primary antiphospolipid syndrome. Vojnosanit Pregl. 2014 Aug:71(8):742-5.

7. Kwak-Kim J, Agcaoili MS, Aleta L, Liao A, Ota K, Dambaeva $\mathrm{S}$, et al. Management of women with recurrent pregnancy losses and antiphospolipid antibody syndrome. Am J Reprod Immunol. 2013 Jun;69(6):596-607. doi: 10.1111/aji.12114

8. Alfirević Z, Roberts D, Nartlew V. How strong is the association between maternal thrombophilia and adverse pregnancy outcome? A systematic review. Eur J Obstet Gynecol Reprod Biol. 2002 Feb;101(1):6-14. doi: 10.1016/S0301-2115(01)00496-1 
9. Rambaldi MP, Mecacci F, Guaschino S, Paidas MJ. Inherited and acquired thrombophilias. Reprod Sci. 2014 Feb;21(2):16782. doi: 10.1177/1933719113497282

10. Bates SM, Greer IA, Middeldorp S, Veenstra DL, Prabulos AM, Vandvik PO. VTE, thrombophilia, antithrombotic therapy, and pregnancy. In: Antithrombotic Therapy and Prevention of Thrombosis, 9th ed. American College of Chest Physicians Evidence Based Clinical Practice Guidelines. Chest. 2012 Feb;141(2 Suppl):e691S-736S. doi: 10.1378/chest.11-2300

11. Redman CWG, Sargent IL. Pre-eclampsia, the placenta and the maternal systematic inflammatory response - a review. Placenta. 2003 Apr;24 Suppl A:S21-S7. doi: 10.1053/plac. 2002.0930

12. de Boer K, ten Cate JW, Struk A, Borm JJ, Treffers PE. Enhanced thrombin generation in normal and hypertensive pregnancy. Am J Obstet Gynecol. 1989 Jan;160(1):95-100. doi: 10.1016/0002-9378(89)90096-3
13. Said JM, Higgins JR, Moses EK, Walker SP, Borg AJ, Monagle $\mathrm{PT}$, et al. Inherited thrombophilia polymorphisms and pregnancy outcomes in nulliparous women. Obstet Gynaecol. 2010 Jan;115(1):5-13. doi: 10.1097/AOG.0b013e3181c68907

14. Clark P, Walker ID, Govan L, Wu O, Greer IA. The GOAL study: a prospective examination of the impact of factor $\mathrm{V}$ Leiden and $\mathrm{ABO}(\mathrm{H})$ blood groups on haemorrhagic and thrombotic pregnancy outcomes. Br J Haematol. 2008 Jan: 140(2):236-40. doi: 10.1111/j.1365-2141.2007.06902.x

15. Dizon-Townson D, Miller C, Sibai B, Spong CY, Thom E, Wendel G Jr, et al. The relationship of the factor V Leiden mutation and pregnancy outcomes for mother and fetus. Obstet Gynaecol. 2005 Sep;106(3):-517-24.

16. Regan L, Backos M, Rai R. The Investigation and Treatment of Couples with Recurrent First-Trimester and Second-Trimester Miscarriages. Royal College of Obstetricians and Gynaecologists Green-top Guideline No.17. RCOG Press, London 2011.

Sažetak

\title{
VAŽNOST PRIMJENE NISKOMOLEKULARNOG HEPARINA KOD TRUDNICA S NASLJEDNOM TROMBOFILIJOM ZA DOBAR PERINATALNI ISHOD
}

\author{
V. Sokol, M. Ivaniševič, M. Herman i J. Đelmiš
}

Cilj ove studije bio je ustanoviti komplikacije trudnoće i važnost primjene niskomolekularnog heparina za poboljšanje perinatalnog ishoda kod trudnica s nasljednom trombofilijom. Retrospektivno su analizirani podatci 70 trudnica s dokazanom hereditarnom trombofilijom i urednom ili opterećenom opstetričkom anamnezom koje su porođene u Klinici za ženske bolesti i porođaje u razdoblju od siječnja 2014. do siječnja 2015. Njih 57 liječeno je niskomolekularnim heparinom, dok kod ostalih 13 žena nije provedena antikoagulantna terapija. Ispitanice s nasljednom trombofilijom koje su tijekom trudnoće uzimale heparinsku terapiju imale su statistički značajno bolji perinatalni ishod u odnosu na ispitanice s nasljednom trombofilijom bez antikoagulantne terapije $(p=0,006)$. Ispitanice s hereditarnom trombofilijom i urednom opstetričkom anamnezom imale su statistički značajno bolji perinatalni ishod u odnosu na ispitanice s trombofilijom i prethodnim habitualnim pobačajima $(\mathrm{p}=0,035)$ ili intrauterinom smrti čeda $(\mathrm{p}=0,033)$. Ispitanice s hereditarnom trombofilijom i urednim prethodnim trudnoćama koje su liječene heparinom imale su nešto bolji perinatalni ishod u odnosu na skupinu s trombofilijom i prethodnim mors fetus in utero kod kojih je također primjenjivana antikoagulantna terapija ( $\mathrm{p}=0,088)$. U skupini ispitanica s hereditarnom trombofilijom a bez heparinske terapije, ispitanice bez habitualnih pobačaja u anamnezi imale su statistički značajno bolji perinatalni ishod u odnosu na trudnice s habitualnim pobačajima $(\mathrm{p}=0,047)$. Primjena niskomolekularnog heparina za bolji perinatalni ishod opravdana je kod trudnica s nasljednom trombofilijom i opterećenom opstetričkom anamnezom.

Ključne riječi: Trombofilija, nasljedna; Trudnoća; Heparin, niskomolekularni; Trudnoća, ishod 